\title{
Vplivi in posledice prostorske segregacije Romov na mestnih območjih - madžarske študije primera
}

Avtorji v članku proučujejo prostorsko segregacijo in njene značilnosti v srednje velikih in majhnih mestih $\mathrm{v}$ madžarski statistični regiji Južna velika nižina, pri čemer predstavijo glavne značilnosti in gonilne sile segregacije, ki so povezane s postkomunističnim razvojem mest. Sprašujejo se predvsem o tem, kako so segregacijski procesi povezani $\mathrm{z}$ etničnimi vprašanji in bivalnimi razmerami ter kaj lahko za rešitev tega problema stori lokalna oblast. Končna ugotovitev je, da je prostorska segregacija v madžarskih kmetijskih mestih pogost pojav. V nekaterih pogledih so tovrstni procesi podobni tistim $\mathrm{v}$ Zahodni Evropi in ZDA, vendar se od njih tudi razlikujejo. Izsledki raziskave opozarjajo na pomembnost kompleksnega razmišljanja o družbenem vključevanju, lokalnem načrtovanju in učinkovitejši dodelitvi finančnih sredstev.

Ključne besede: prostorska segregacija, majhna in srednje velika mesta v postkomunističnih državah, romska etnična manjšina, razvoj mest 


\section{Uvod}

Segregacija je dobro raziskan in splošno znan družbeni pojav, ki lahko vključuje različne družbene skupine na podlagi rase, etnične pripadnosti, veroizpovedi ali spolne identitete ter ima najrazličnejše oblike - od izobraževalne, poklicne do prostorske (glej na primer White, 1983; Massey in Denton, 1993; Clark in Ware, 1997; Marcuse, 1997; Bjorvatn in Cappelen, 2001; Charles, 2003; Musterd, 2003; Zhang, 2006; Logan in Stults, 2011). Avtorji se v članku osredotočajo na značilnosti prostorske ali geografske segregacije v majhnih in srednje velikih mestih v madžarski statistični regiji Velika južna nižina. V večjih mestih v ZDA in Zahodni Evropi je prostorska segregacija (ang. residential segregation) običajno dobro raziskana in dokumentirana, veliko manj pa je znanega o značilnostih tega procesa $\mathrm{v}$ postkomunističnih državah in zlasti mestih $\mathrm{z}$ manj kot 200.000 prebivalci (glej na primer Gentile, 2004; Gyenizse idr. 2016). Prostorska segregacija je bil ključni pojav v zgodovinskem razvoju proučevanih naselij, izsledki te raziskave pa kažejo, da je v mestnem življenju še vedno prisotna. Čeprav ni tako opazna kot $\mathrm{v}$ večjih mestih (podobno kot pri mestni in podeželski revšcini), gre za pomemben problem, ki ga je treba rešiti, če želimo zagotoviti trajnostno prihodnost.

Vključitev vzhodnoevropskih postkomunističnih držav v Evropsko unijo je prinesla številne prednosti z vidika nadaljnjega izvajanja raznih razvojnih politik. Med njimi je tudi urbanistična politika, pri kateri so morali strokovnjaki opustiti tehnični pristop, ki je prevladoval v obdobju državnega socializma, in $\mathrm{v}$ načrtovalsko prakso vključiti nove vidike in metode. Tako so socialni problemi in konflikti ter njihovi vplivi na rabo mestnega prostora začeli pritegovati več pozornosti. $\mathrm{V}$ prejšnjem in sedanjem načrtovalskem obdobju EU so morala mesta pripraviti t. i. strategijo celostnega razvoja mest, ki je bila nujen pogoj za pridobitev subvencij EU. Eden izmed obveznih delov tega strateškega razvojnega dokumenta je tudi protisegregacijski načrt poselitve. Zahteve za izdelavo tega načrta temeljijo na zakonodaji in priporočilih $\mathrm{EU}$ ter se tematsko osredotočajo na prostorsko segregacijo, pri čemer uporabljajo skupno metodologijo za zamejevanje in opis segregiranih območij. Prej so morali tovrstne načrte izdelovati samo sedeži županij in druga mesta s pravicami županije, v pripravah na programsko obdobje 2014-2020 pa je madžarska vlada to obveznost razširila tudi na središča mikroregij. To omogoča celostno analizo prostorske segregacije v majhnih in srednje velikih madžarskih mestih. Avtorji so za podrobnejšo raziskavo izbrali mesta v statistični regiji Južna velika nižina in mesto Kecskemet, saj so to območje že prej proučevali, sodelovali pa so tudi pri izdelavi nekaterih regionalnih in mestnih strateških in načrtovalskih dokumentov in projektov - na primer pri strategiji celostnega razvoja mesta Kecskemet iz leta 2008 in njenih sprememb iz leta 2013, protisegregacijskem načrtu za mesto Kecskemet iz leta 2008 in njegovih spremembah iz let 2013 in 2017, pri projektih Innoaxis HU-SRB IPA in Lolamar HU-SRB IPA, razvojnem konceptu županije Bacs-Kiskun iz leta 2013, programu kompleksnih raziskav podeželja na podlagi sodelovanja med madžarsko akademijo znanosti in madžarsko nacionalno mrežo za podeželje za obdobje 2012-2013, strategiji razvoja raztresenih kmetij v mikroregiji Kecskemet iz leta 2013 in presoji trga dela v županiji Bacs-Kiskun iz leta 2017.

Avtorji se ukvarjajo z naslednjimi raziskovalnimi vprašanji:

- Kako pogosta je prostorska segregacija v majhnih in srednje velikih mestih v statistični regiji Velika južna nižina in kje $\mathrm{v}$ teh mestih so prostorsko segregirana območja?

- Katere so glavne značilnosti in gonilne sile prostorske segregacije? Lahko določimo katere koli edinstvene poteze, ki so povezane $s$ postkomunističnim urbanim razvojem srednje velikih mest?

- Kako so ti procesi povezani z etničnimi vprašanji in bivalnimi razmerami?

- Kaj lahko lokalna uprava stori za rešitev tega problema?

\section{Teoretično ozadje}

V splošnem se prostorska segregacija nanaša na to, v kakšni meri dve skupini ali več živijo ločeno druga od druge v različnih delih mestnega okolja (Massey in Denton, 1988: 282). Na različnih ravneh pestre realnosti gre pri segregaciji (skupaj s polarizacijo in izključevanjem) za izredno raznolik proces, njegove posledice pa imajo najrazličnejše prostorske oblike (Park idr. 1925; Burgess, 1928; Duncan in Duncan, 1955a, 1955b; Glazer in Moynihan, 1963; Lieberson, 1963; Taeuber in Taeuber, 1965; Morgan in Norbury, 1981; Hamnett, 2005, 2010). Kot lahko povzamemo iz dela Residential segregation in comparative perspective: Making sense of contextual diversity, je prostorska segregacija večdimenzionalen družbeni pojav, tesno povezan $s$ prostorsko ločenostjo družbenih skupin v naselju ter razlikami $\mathrm{v}$ socialnih in naravnih razmerah med različnimi predeli in soseskami (Maloutas in Fujita, 2012).

Prostorska ali družbeno-prostorska segregacija je običajno posledica različnih dejavnikov. Ti dejavniki so lahko splošni (na primer gospodarske spremembe) ali lokalni (na primer razvoj urbanih območij in infrastrukture), drugi avtorji pa trdijo, da je najmočnejši tovrstni dejavnik rasna ali etnična razdeljenost družbe (Musterd in Ostendorf, 1998; Márquez, 2011; Bolt idr. 2012; Lloyd idr. 2014; Sabater in Finney, 2014). Poleg tega je prostorska segregacija močno povezana $\mathrm{z}$ dohodkovno neenakostjo med družbenimi ali med etničnimi skupinami, kar se po mnenju številnih avtorjev kaže tudi v značilnostih grajenega okolja (Schelling, 1971, 1978; Charles, 2001; Logan idr. 2004; 
Watson, 2006; Spielman in Harrison, 2013; Anthopolos idr. 2014; Bellman, 2014). Avtorji v tem članku podrobneje proučujejo ta pojav. Premožnejše skupine v posameznih lokalnih skupnostih se poskušajo kar se da ločiti od socialno ogroženih skupin prebivalstva, kar samo še slabša razmere in krepi prostorske razlike v mestu.

Avtorji se strinjajo s hipotezo, da je prostorska segregacija globalni konstrukt in da imajo družbene razlike v ZDA, Zahodni Evropi in postkomunističnih državah podobno prostorsko obliko (Massey in Denton, 1988). Družbena neenakost in njena prostorska posledica - prostorska segregacija (razlikovanje) obstajata v vseh naprednih družbah (Vaattovaara, 2002: 108). Po mnenju avtorjev lahko zato konflikte in procese z začetka 20. stoletja, obravnavane $\mathrm{v}$ mednarodni literaturi, prenesemo tudi na sedanje razmere (Duncan in Duncan, 1957; Howell in Timberlake, 2014). Študije primera, predstavljene v tej literaturi, so zelo podobne nedavnim segregacijskim procesom v vzhodnoevropskih mestih, tako z vidika socialnih konfliktov kot prostorskih vzorcev (Kovacs, 2012). Primeri rasne segregacije, ki jo $\mathrm{v}$ ZDA proučujejo od začetka 20. stoletja, so zelo podobni pojavu getov v vzhodnoevropskih mestih (Farley idr., 1997). Na Madžarskem se danes to nanaša na dobršen del romskih prebivalcev, ki živijo v slabih razmerah in na prostorsko segregiranih mestnih območjih. Vse to odpira staro vprašanje, ali obstajajo splošne gonilne sile prostorske segregacije ali pa lokalne razmere določajo razlike med posameznimi mestnimi območji. Rezultati raziskave, predstavljene $\mathrm{v}$ tem članku, dajejo dodatne informacije, na podlagi katerih lahko lažje odgovorimo na to vprašanje.

\section{Zgodovinski temelji prostorske segregacije v madžarskih mestih}

Čeprav prostorska segregacija na Madžarskem ni povezana samo s položajem romskega prebivalstva, so najbolj pereči problemi, ki se danes pojavljajo na tem področju, običajno povezani prav z Romi. Zato se tudi ta kratki zgodovinski pregled $\mathrm{v}$ glavnem osredotoča na njihov položaj v zadnjih stoletjih. Pred letom 1848 je bila v fevdalni Madžarski pogosta prostorska segregacija na podlagi pravnega položaja naselja (plemiške ali kmečke vasi), veroizpovedi (židovske četrti) in etnične pripadnosti (nemška ali slovaška mesta in vasi). Po koncu turške vladavine, ki se je končala okoli leta 1700, so se prej nomadski Romi postopno ustalili na Madžarskem in našli svoj prostor v opisanem sistemu. Med vladavino Marije Terezije (17401780) je bil ta proces naseljevanja še pospešen in prepovedana je bila prostorska segregacija romskih prebivalcev. Kljub temu so v tem obdobju nastala prva romska naselja (Csalog, 1984), in sicer na območjih, manj ugodnih za gradnjo (na primer na območjih, ki so jih ogrožale poplave ali narasla podtalnica, ter v bližini odlagališč odpadkov ali pokopališč) (Kallai in Törzsök, 2006). Ulična imena $\mathrm{v}$ teh naseljih še vedno kažejo zgodovinsko funkcijo teh lokacij. Na začetku 20. stoletja je $90 \%$ Romov živelo na prostorsko segregiranih območjih, hkrati pa se je slabšal tudi njihov položaj na trgu dela. Nekateri poklici, v katerih so bili Romi tradicionalno zaposleni, so hitro izgubljali pomen (Csalog, 1984). Zaradi obsežnega prestrukturiranja trga dela in svetovne gospodarske krize med obema svetovnima vojnama je bil velik del madžarskih prebivalcev potisnjen na dno družbene lestvice in prisiljen živeti v soseskah, ki so bile podobne romskim. Poleg teh so na Madžarskem obstajale še druge oblike prostorske segregacije, na primer bivališca kajžarjev ali bivališča, izklesana v skalo, v regiji Bükkalja (Illyes, 1936; Szabo, 1937). V teh bivališčih so najprej živeli revni kmetje, pozneje pa so se vanje naselili Romi (Kemény, 2000).

Po drugi svetovni vojni so se v novem komunističnem režimu bivalne razmere socialno najbolj ogroženih skupin izboljšale in družbene neenakosti so se zmanjšale. Prisilna stalinistična industrializacija je (kljub vsem njenim nepravilnostim) omogočila zaposlitev delovni sili, ki je zapuščala primarni sektor, in v ta proces ji je uspelo vključiti tudi Rome. Romski moški so v tem obdobju celo dosegli idealistični komunistični cilj redne zaposlitve (Csalog, 1984). V nasprotju z vključevanjem na trg dela je odprava prostorske segregacije potekala zelo počasi, kar je bilo delno povezano s hitrim širjenjem mest, zaradi katerega slumi na obrobju mest prostorsko niso bili več tako izolirani od preostalega mestnega območja. Centralno načrtovana odstranitev romskih sosesk in naselij je bila izvedena veliko pozneje, in sicer šele leta 1961, ko je madžarska socialistična delavska stranka sprejela sklep, ki je pomenil prelomnico v tem procesu (Kocsis in Kovacs, 1999). Načrtovalske dejavnosti so vključevale odstranitev številnih naselij, ki so obstajala več stoletij, in zaradi teh ukrepov so se bivalne razmere romskih prebivalcev vsaj delno izboljšale. Osnovnih ciljev programa, kot sta odprava prostorske segregacije in zmanjšanje razlik v bivalnih razmerah, pa kljub temu ni bilo mogoče doseči, in sicer zato, ker:

- so se nekatere romske soseske izognile rušenju, vendar so bile zaradi centralno načrtovane politike razselitve Romov izključene iz gradnje najosnovnejše infrastrukture;

- nekatere lokalne oblasti niso upoštevale uredbe o razpršeni ponovni naselitvi Romov in so jih pogosto preselile na geografsko podobno neugodna območja kot prej. $\mathrm{Na}$ teh območjih so bili zgrajeni zaprti urbani bloki s stavbami nižje kakovosti ali hišami z oznako Cs (začetni črki madžarske besede csökkentett 'nižje vrednosti'), $k i$ niso pripomogle $k$ zmanjšanju razlik $v$ bivalnih razmerah romskega in večinskega madžarskega prebivalstva. Ulica Piste Danka (madž. Danko Pista utca), poimenovana po znanem madžarskem romskem skladatelju, danes ohranja spomin na te dogodke v madžarskih 


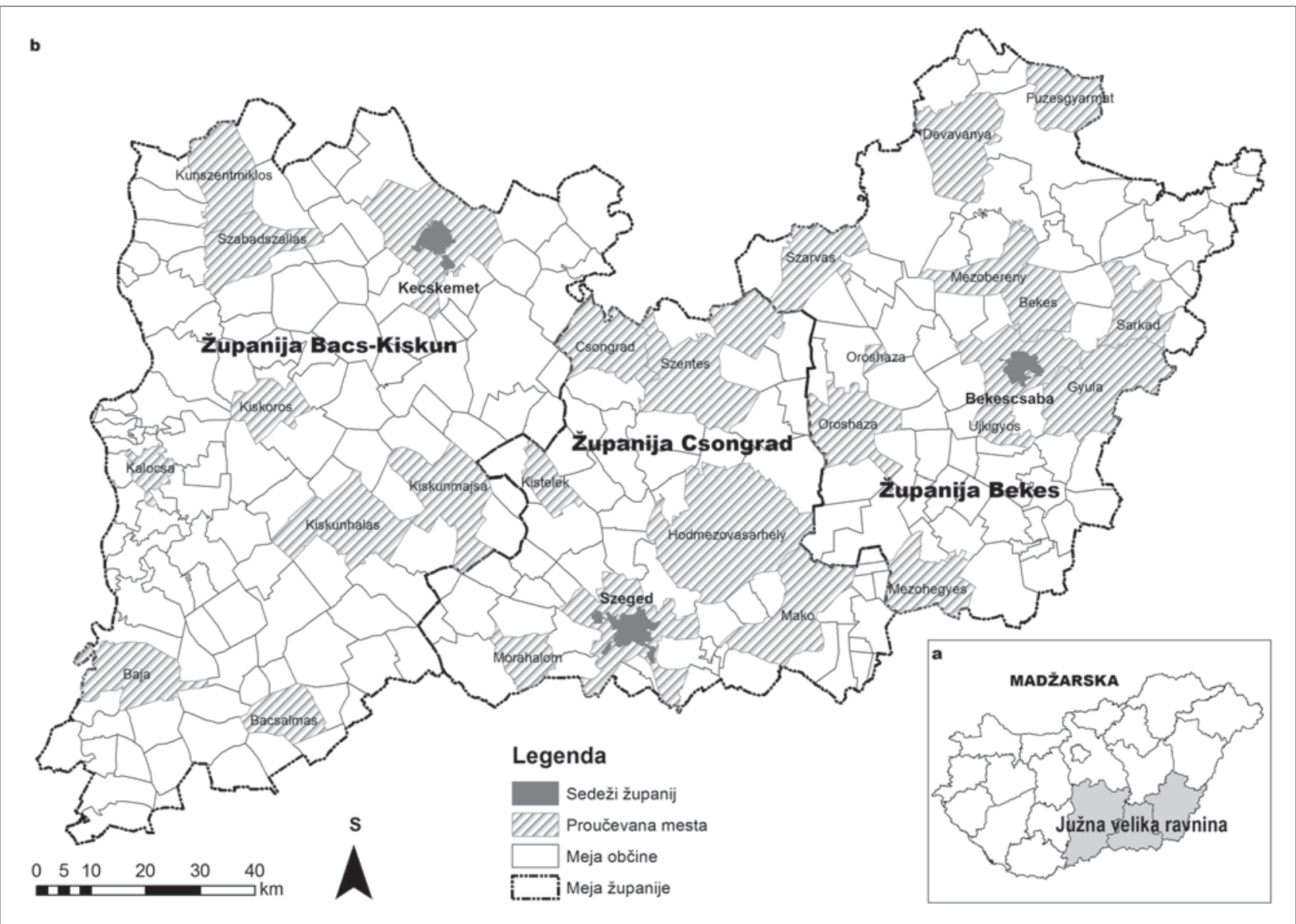

Slika 1: (a) geografska lega proučevanega območja na Madžarskem; (b) proučevana mesta (avtor: Jenö Zsolt Farkas)

naseljih (Csalog, 1984);

- so se v nekaterih primerih razseljeni posamezniki znašli $\mathrm{v}$ še slabših razmerah kot prej, saj so nov dom dobili na kmetijah, ki so svojo funkcijo izgubile zaradi kolektivizacije.

Poleg novih zaprtih urbanih blokov s hišami z oznako Cs so prostorsko segregacijo, ki se je zdaj samo premaknila na druga območja, pospeševali tudi drugi dejavniki, vključno s pogoji za pridobitev posojila za nakup hiše. Najvišji možni znesek posojila je običajno zadoščal samo za nakup nepremičnin $\mathrm{v}$ težko dostopnih majhnih vaseh, $\mathrm{v}$ katerih je število prebivalcev upadalo. Posledično se je začela sestava prebivalstva $v$ teh naseljih hitro spreminjati. $V$ naseljih, kjer so imeli večjo moč lobiranja, so z razseljevanjem svojih romskih prebivalcev v te vasi ta proces še okrepili (Havas, 1999). Zaradi te prakse so $\mathrm{v}$ več naseljih, zlasti v regijah Cserehat in Ormansag, zdaj prevladovali Romi (Ladanyi in Szelenyi, 2004). Podoben proces je povzročil prostorsko zgoščanje prebivalcev z nizkim socialno-ekonomskim položajem v nekdanjih kmetijskih mestih v statistični regiji Južna velika nižina, kjer so raztresena in težko dostopna kmetijska območja postala glavni cilj priseljevanja družbeno izključenih ljudi (Romany, 1973; Csalog, 1984; Vasarus, 2016).

Nekateri procesi, značilni za komunistično obdobje, so se nadaljevali tudi po političnih in gospodarskih spremembah, zaradi manj strogo nadzorovane mobilnosti pa so se pojavile tudi nove smeri razvoja. Zaradi sprememb prebivalstva skozi čas in selektivnih selitev med zaželenimi ali nezaželenimi območji v naseljih se je prostorska segregacija znova okrepila. Lokalni prebivalci z višjimi dohodki so se preselili v predmestja, revnejši prebivalci pa večinoma v vasi zunaj aglomeracij, kar je okrepilo prostorsko ločenost teh družbenih skupin. Zaradi nenehnega večanja deleža romskih prebivalcev v teh vaseh se je izoblikovala nova vrsta segregacije na Madžarskem, pri kateri je bilo prebivalstvo posameznih mikroregij skoraj v celoti sestavljeno iz pripadnikov socialno ogroženih skupin (Virag, 2010). Ti ljudje so bili izključeni $s$ trga dela in mnogi so izgubili svoje življenjske ambicije. Janos Ladanyi in Ivan Szelenyi (2004) zato ta proces opisujeta kot rojstvo socialno zapostavljenega sloja na podeželju. Izsledki terenske raziskave, ki sta jo opravila Istvan Kemeny in Bela Janky (2004), kažejo, da je leta 200372 \% romskih družin živelo na prostorsko segregiranih območjih. 


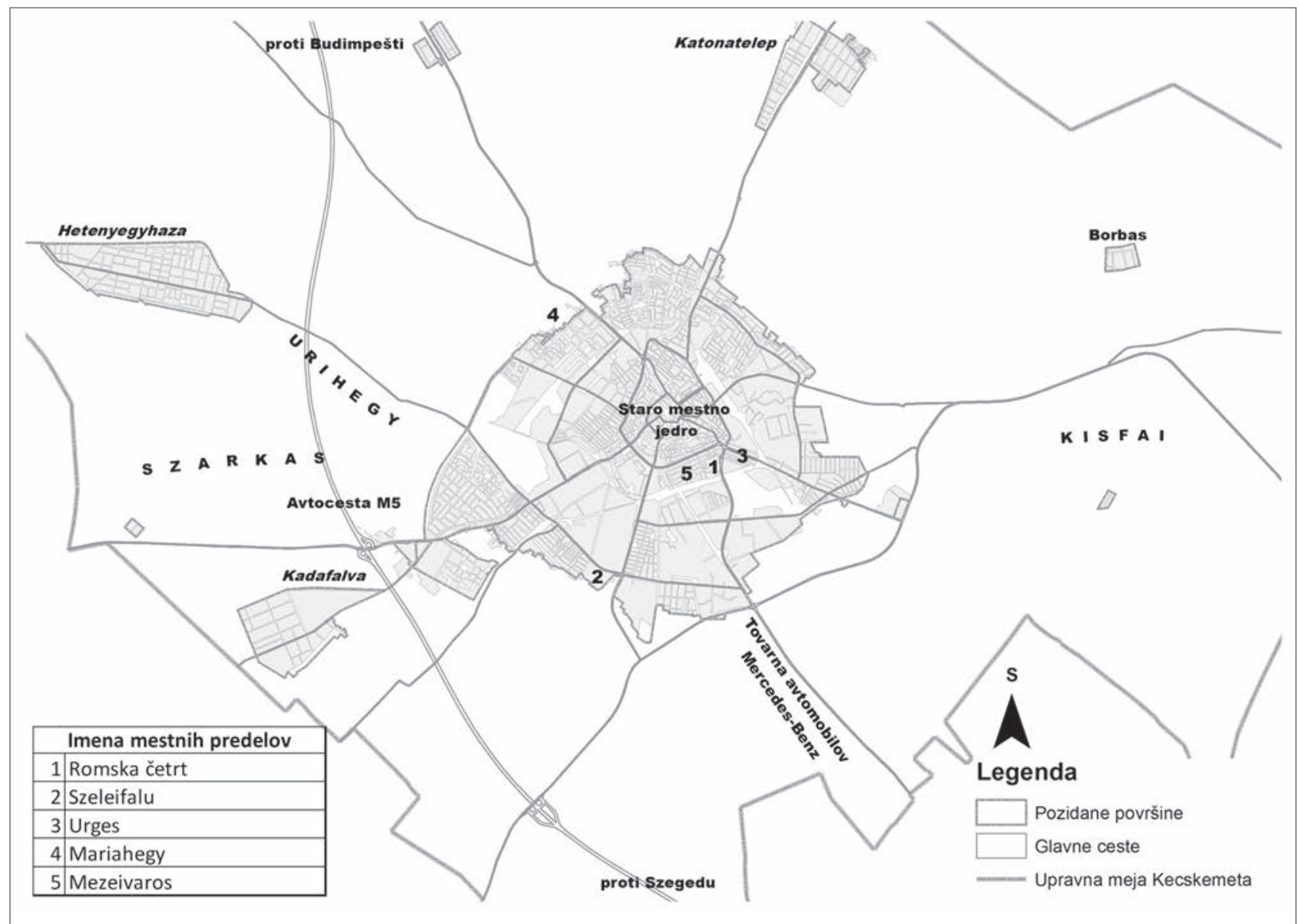

Slika 2: Proučevano območje Kecskemeta z zemljepisnimi imeni, ki se pojavljajo v raziskavi (avtorja: Jenö Zsolt Farkas in Andras Donat Kovacs)

Podobno je pokazala tudi nacionalna raziskava, opravljena leta 2010. V 823 proučevanih naseljih in desetih metropolitanskih okrožjih Budimpešte je bilo odkritih 1.623 prostorsko segregiranih območij, na katerih so živeli ljudje z nizkim socialno-ekonomskim položajem ali Romi (Domokos in Herczeg, 2010). Opisane nedavne raziskave in druge študije kažejo, da je proces vključevanja, ki se je začel v obdobju državnega socializma, zdaj na Madžarskem prekinjen in da problem prostorske segregacije po političnih spremembah spet postaja bolj pereč.

\section{Metodološko ozadje}

\subsection{Proučevano območje}

Madžarska statistična regija Južna velika nižina leži na jugovzhodu države, v njej pa živi 1,3 milijona ljudi oziroma 13,2 \% celotnega madžarskega prebivalstva. Po podatkih madžarskega popisa prebivalstva iz leta 2015 točna številka znaša 1.262 .936 (602.183 moških in 660.753 žensk). Regija je sestavljena iz treh županij: Bacs-Kiskun, Csongrad in Bekes. Kljub nizki gostoti poselitve $\left(72\right.$ ljudi na $\left.\mathrm{km}^{2}\right)$ 67,9\% prebivalcev živi v občinah, ki imajo mestne pravice. Čeprav je statistično gledano ta regija ena najbolj urbaniziranih $\mathrm{v}$ državi, $\mathrm{v}$ mnogih pogledih velja za bolj podeželsko kot urbano. To trditev potrjujejo tudi edinstvene prvine naselbinskega omrežja (trška naselja $\mathrm{z}$ vrtovi in raztresenimi kmetijami, slika 1).

Glavne prvine naselbinske zgradbe so specializirana trška naselja, imenovana tudi kmetijska mesta, ki so bila prvotno središča kmetijske proizvodnje in trgov. Pod turško oblastjo so imela zaščiten status in so se izognila uničenju ( $v$ nasprotju z manjšimi vasmi). Po koncu turške nadvlade so zato naselbinsko omrežje sestavljala redko posejana in skoraj izključno kmetijska mesta. Oddaljenih njiv ni bilo mogoče obdelovati iz središč kmetijskih mest, zaradi česar se je razvil edinstven sistem raztresenih kmetij. Sprva so bile te kmetije (madž. tanya) le občasno naseljene in so delovale kot pomožni zaselki, ki so bili tesno povezani s posameznim kmetijskim mestom. Ta vez je pozneje oslabela in raztresene kmetije so se začele uporabljati kot stalna bivališča. Število prebivalcev na mestnem obrobju je doseglo višek šele po drugi svetovni vojni in do takrat je edinstvena dvojnost kmetijskih mest in raztresenih kmetij že zdavnaj zbledela, gruče raztresenih kmetij pa so se začele čedalje bolj povezovati v vasi. V zadnjih petdesetih letih se je število prebivalcev na obrobju mest po vsej državi zmanjšalo 
s približno enega milijona na približno 300.000 (podatki za leto 2011), pri čemer obstajajo precejšnje prostorske razlike. Tako je na območju Južne velike nižine (zlasti na predelu med Donavo in Tiso ter v županiji Bekes) delež prebivalcev, ki živijo na obrobju mest, še vedno večji od državnega povprečja.

Med komunizmom je bila industrializacija trških naselij zelo različna. Mesta $\mathrm{z}$ več prebivalci so izgubila svojo primarno kmetijsko funkcijo ter se spremenila v industrijska in storitvena središča. Eno najpomembnejših regionalnih središč je Kecskemet, ki ima 117.000 prebivalcev. V zadnjih nekaj letih se je zaradi največje tuje naložbe $\mathrm{v}$ tej regiji (leta 2009 je skupina Daimler odprla tovarno avtomobilov Mercedes-Benz) spremenil v edinstveno tradicionalno kmetijsko mesto. Na podlagi te naložbe so lahko mestne oblasti obnovile urbane bloke v skladu s potrebami mesta in tovarne. Šlo je za edinstveno priložnost, saj so drugače možnosti na tem področju odvisne predvsem od subvencij EU. To je bil glavni razlog, da so avtorji Kecskemet izbrali za študijo primera, drugi razlog, opisan v nadaljevanju, pa je bilo dejstvo, da so v tem mestu vse oblike prostorske segregacije (slika 2).

Kecskemet je 650 let staro mesto, na nastanek njegovih sosesk ali predelov pa so vplivali številni naravni in družbeni dejavniki. Mesto sprva ni imelo urejene prostorske zgradbe in izoblikovanih sosesk, na začetku 15. stoletja pa so se že začele kazati prve razlike med mestnimi predeli - zlasti med stanovanjskimi območji, ki so nastala v tem obdobju. Premožnejši prebivalci so živeli v središču mesta, ki je sovpadalo z današnjim glavnim trgom in njegovo okolico, manj premožne skupine pa so živele na obrobju pozidanega mestnega območja in so bile od njih izrazito prostorsko ločene. Sredi 18. stoletja je začelo število prebivalcev naraščati, kar je še povečalo razlike v lokalni družbi, $\mathrm{v}$ tem času pa se je pojavila tudi klasična oblika prostorske segregacije. Zaradi pogostih požarov so mestne oblasti uvedle gradbene predpise (Juhasz, 1998), pri katerih je bil glavni poudarek na načrtovanju ulic in pravilih glede uporabe gradbenih materialov. $\mathrm{V}$ središču mesta so lahko na primer gradili samo z opeko, ki si je revne družine niso mogle privoščiti, zato so mestne oblasti zanje določile zazidljive parcele na robu pozidanega območja. Šlo je za večinoma nižinska območja, ki so bila občasno poplavljena in zato slabo dostopna, tamkajšnje bivalne razmere pa so bile slabe in zdravju škodljive, saj so bili zidovi hiš stalno vlažni. Zaradi prostorske segregacije revnejših prebivalcev in Romov so se v lokalni družbi pojavljale razne težave, hkrati pa so se na mestnem obrobju pojavile tudi že prve raztresene kmetije.

Vse do prve svetovne vojne je bil za Kecskemet značilen izjemen razvoj industrije in kmetijskega trga, kljub temu je mestno središče ostajalo le jedro večje vasi. Njegova metropolitanska podoba se ni razširila na stanovanjska območja in prostorsko segregirani predeli na obrobju mesta so samo še krepili njegovo kmečko podobo. Med obema vojnama se je mesto z vidika gospodarske funkcije iz kmetijskega središča spremenilo $\mathrm{v}$ sodobnejše kmetijsko-industrijsko regionalno središče, pri čemer se je spremenila tudi zaposlitvena sestava prebivalcev. Med svetovno gospodarsko krizo (1929-1933) je gospodarstvo stagniralo in prekinilo razvoj Kecskemeta, kar je povzročilo socialne probleme, kot je splošna revščina. Socialne razlike in prostorska segregacija so se zato še okrepile. $\mathrm{Na}$ tisoče ljudi se je $\mathrm{v}$ tem obdobju preselilo $\mathrm{v}$ hiše, zgrajene iz gline in slame. Najznačilnejši segment lokalne družbe so bili vedno Romi, katerih asimilacija ni bila uspešna. Njihov geografsko izolirani geto, imenovan romska četrt, so porušili šele leta 1963 v skladu s splošno politiko komunistične države. Mestne oblasti so morale zagotoviti nove domove skoraj tisoč ljudem, pri čemer so zazidalna zemljišča zanje razporedila po robu mestnega pozidanega območja, družine pa so preselile tudi v stare razpadajoče hiše v središču mesta. Številne družine, ki so takrat dobile zazidljive parcele, so si čez nekaj let s posojili kupile blokovska stanovanja ali so se preselile v okoliške vasi.

Med prehodom iz komunizma v demokratični politični sistem so se $\mathrm{v}$ zapuščene barake romske četrti preselile nove romske družine iz drugih naselij. V nekaterih ulicah v širši okolici nekdanje romske četrti je začel delež romskih prebivalcev posledično naraščati, pripadniki večinskega prebivalstva pa so se preselili v novo zgrajena lastniška stanovanja ter v nove soseske, zgrajene po zgledu vrtnega mesta, in v predmestje. To je bil še zadnji korak, ki je ustvaril zdajšnje problematične razmere, v katerih Romi spet živijo prostorsko segregirano, kar pušča izrazito sled $\mathrm{v}$ mestnem tkivu.

\subsection{Uporabljene metode}

Za iskanje odgovorov na zastavljena raziskovalna vprašanja so avtorji uporabili več metod: analizo dokumentov in podatkov GIS, intervjuje in terenske raziskave. V okviru regionalnega pregleda prostorske segregacije so proučili strategije celostnega razvoja 27 mest v statistični regiji Južna velika nižina. Ti dokumenti so dostopni na madžarskem spletnem portalu za prostorsko načrtovanje in regionalni razvoj Terport (internet 1). Rezultati teh strategij so med sabo primerljivi, saj so mesta za oblikovanje protisegregacijskih načrtov uporabljala skupno metodologijo, ki jo je razvilo madžarsko ministrstvo za lokalno upravo in regionalni razvoj (internet 2). Podobne metode so avtorji uporabili tudi za analizo prostorske segregacije v Kecskemetu. Tamkajšnja prostorsko segregirana območja so bila prvič uradno obravnavana v protisegregacijskem načrtu strategije celostnega razvoja mesta iz leta 2008. Avtorji tega članka so imeli pomembno vlogo pri izdelavi tega načrta, $v$ okviru katerega je bilo v Kecskemetu odkritih osem segregiranih območij (internet 3). Za določanje teh območij so 


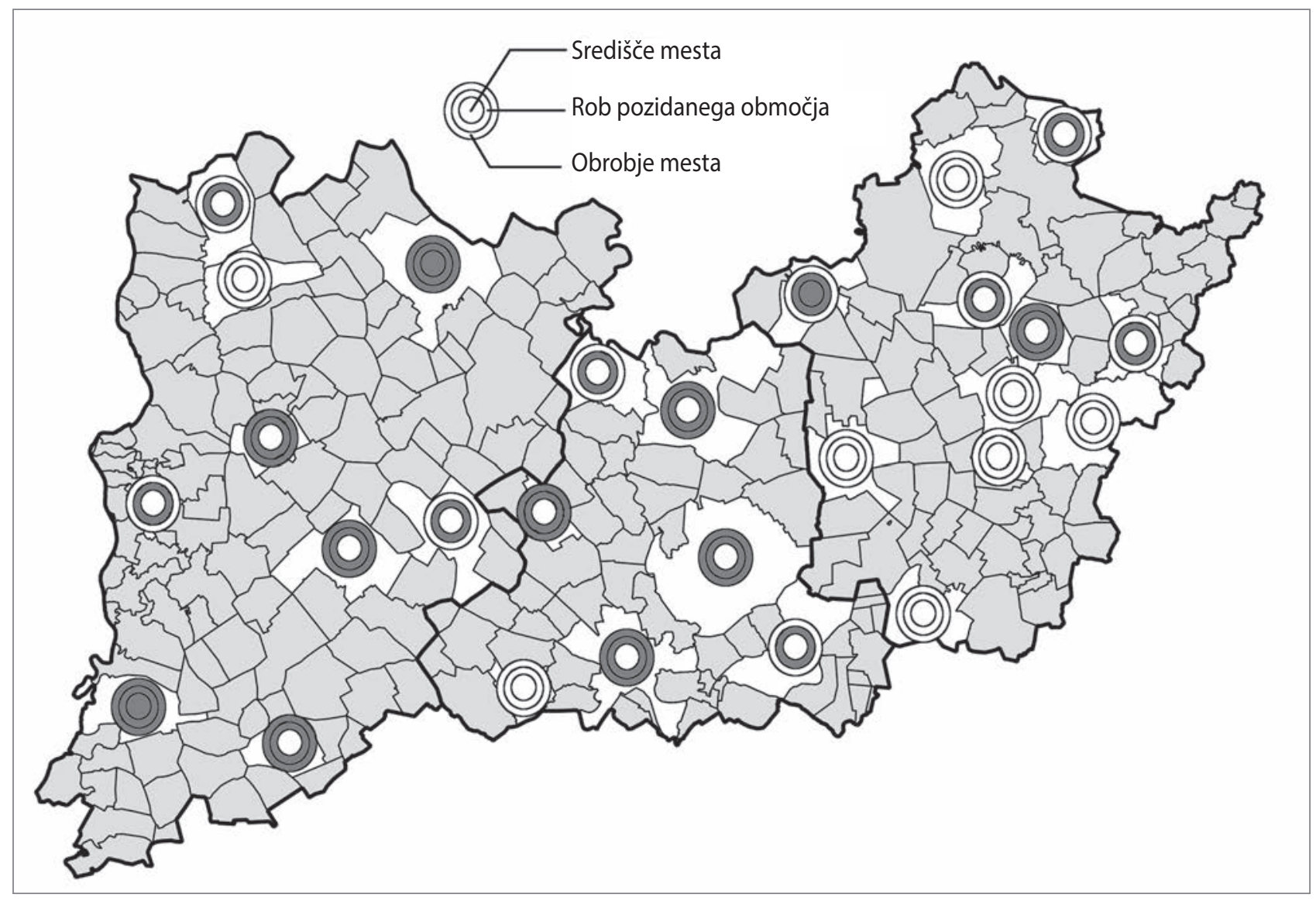

Slika 3: Prostorsko segregirana območja v proučevanih mestih (avtor: Jozsef Lennert)

uporabili metodo, predstavljeno v posebnem priročniku za urbano prenovo mest (internet 2). Nekaj let pozneje (leta 2014) so avtorji nadaljevali raziskavo, saj je bilo treba znova ovrednotiti območja segregacije v mestu. Metodologijo je razvilo madžarsko ministrstvo za nacionalni razvoj in gospodarstvo ter jo leta 2009 objavilo v drugi izdaji zgoraj omenjenega priročnika (internet 4 ). V skladu s priročnikom so se prostorsko segregirana stanovanjska območja lahko določila na podlagi dveh meril:

- urbani bloki, kjer vsaj $50 \%$ prebivalcev, starih od 15 do 59 let, nima rednega dohodka in osnovnošolske izobrazbe (tj. ima dokončanih manj kot osem razredov osnovne šole),

- urbani bloki, kjer je delež rednih prejemnikov socialne podpore več kot dvakrat večji od mestnega povprečja.

Poleg tega vsebuje priročnik še en pomemben pogoj, in sicer da mora imeti prostorsko segregirano stanovanjsko območje vsaj 50 prebivalcev. $S$ tem izločimo vse posamezne primere, pri katerih dejansko ne gre za segregacijo. Rezultati analize, ki so jo opravili avtorji, kažejo, da je večina mest na proučevanem območju pri svojih razvojnih strategijah uporabljala obe zgoraj opisani merili. Pri raziskavi Kecskemeta so ju uporabili tudi avtorji, poleg tega pa so proučili tudi strategijo razvoja mesta Kecskemet za obdobje 2013-2015 (internet 5), protisegregacijski načrt za mesto Kecskemet za obdobje 2014-2020 (internet 6; pri izdelavi katerega so tudi sami sodelovali), podatke popisa prebivalstva iz leta 2011 in podatkovne zbirke agencije za razvoj mesta Kecskemet, ki so vsebovale podatke o socialnovarstvenih prejemkih. Podatke popisa so pridobili od madžarskega centralnega statističnega urada (MCSU); ti podatki so bili že geokodirani in so nakazovali mogoča območja prostorske segregacije. Neobdelane socialnovarstvene podatke so morali najprej geokodirati, na podlagi česar so določili morebitna območja, na katerih živijo ljudje z nizkim socialnoekonomskim položajem, in rezultate navzkrižno primerjali z rezultati, ki so jih dobili od MCSU. Postopek geokodiranja in $\mathrm{z}$ njim povezano prostorsko analizo so opravili v programu ArcGIS (internet 7). Za boljše razumevanje procesov, ki potekajo na ugotovljenih prostorsko segregiranih območjih, so opravili 34 poglobljenih intervjujev s predstavniki mestnih oblasti in agencije za razvoj mesta, socialnimi delavci in člani romske skupnosti. Poleg tega so proučili tudi druge ustrezne dokumente mestne uprave in njene projektne dejavnosti na zadevnem področju. 


\section{Rezultati}

Analiza razvojnih dokumentov je potrdila prejšnje ugotovitve avtorjev glede Kecskemeta. Ljudje z nizkim socialno-ekonomskim položajem se zgoščajo na treh območjih v okviru upravnih meja proučevanih kmetijskih mest: 1 . v središču mest, 2. na robu pozidanega območja mest ali 3. na obrobju mest (na sliki 3 so prikazana za vsako proučevano mesto).

Kot je bilo opisano že v primeru Kecskemeta, so bili zgodovinski procesi segregacije na teh območjih zelo različni in zato je tudi njihov današnji položaj zelo različen. V nadaljevanju so povzete značilnosti posameznih območij segregacije.

Prostorska segregacija v središču mest je najtesneje povezana z modelom koncentrične urbane ekologije, ki so ga razvili Robert Ezra Park idr. (1925). V svoji raziskavi so odkrili prostorsko segregirano območje okrog poslovnega središča Chicaga. V kmetijskih mestih proučevanega območja (v Baji, Kecskemetu in Szarvasu) je mogoče najti samo tri podobne točke, kar pomeni, da za območje Južne velike nižine ta oblika prostorske segregacije ni značilna. Glavni razlogi za to so razmeroma majhna mestna središča, dejstvo, da tam ni starih stavb (v katerih bi stanovali revni prebivalci), in trajna prisotnost slumov na robu pozidanih območij. V mestih z večjim številom prebivalcev ima pomembno vlogo tudi suburbanizacija, ki se je začela v osemdesetih letih 20. stoletja (Meszaros, 1990; Timar, 1993). V takšnih mestih so se premožnejši prebivalci preselili v predmestja ali okoliške vasi, zaradi česar so se lahko na njihova mesta naselili revnejši prebivalci (večinoma Romi). Zaradi različne prostorske zgradbe treh proučevanih mest so tudi bivalne razmere v njih zelo različne. V Baji Romi živijo na notranjih dvoriščih stavb, kar je na primer značilno tudi za središče Budimpešte. V Szarvasu so se naselili na območju samostojnih hiš z vrtovi, v Kecskemetu pa je več manjših segregiranih območij v mestnem središču, ki danes tvorijo povezavo do tradicionalno romskih predelov na jugovzhodu mesta.

Od 27 ugotovljenih primerov segregacije v mestih v statistični regiji Južna velika nižina jih je 19 na robu pozidanih območij, zaradi česar je to najpogostejša oblika prostorske segregacije na proučevanem območju. Tudi predel z največjim številom romskih prebivalcev (2.959 leta 2001) je na robu pozidanega območja v Maku. Točke, na katerih se zgoščajo prebivalci z nizkim socialno-ekonomskim položajem, so nastajale skozi celotno zgodovino mest. V nekaterih primerih so bila ta območja v komunističnem obdobju porušena (na primer v Kecskemetu in Szentesu), vendar jih je mogoče še vedno najti v bližini. To je posledica napačne prakse mestnih oblasti, ki so te ljudi v skupinah preselile na podoben kraj v soseski, kar pomeni, da težave niso rešile, ampak samo prestavile drugam. Značilna prvina teh območij so hiše z oznako Cs. Tamkajšnje naravne razmere so neugodne (visok nivo podtalnice) in otežujejo vsakdanje bivalne razmere (zidna plesen). Tudi infrastruktura na teh območjih je običajno v slabem stanju ali je sploh ni. Prebivalci proučevanih mest ta območja včasih poznajo samo po njihovih neformalnih imenih, kot sta Mali Dunaj (madž. Kis Bécs) v Maku ali Krakov (madž. Krakkó) v Szarvasu. Prostorsko segregirano in podstandardno območje v Füzesgyarmatu, imenovano Blatni otok (madž. Sársziget), je sestavljeno iz socialnih stanovanj ali hiš, ki so v madžarščini označene $\mathrm{z}$ okrajšavo ONCsA in so jih med drugo svetovno vojno zgradili za pomoč velikim družinam. Ta primer kaže, da je geografska segregacija mogoča tudi na posebnih stanovanjskih območjih, ki so bila prvotno zgrajena s plemenitimi nameni.

Tretje območje, na katerem se zgoščajo revnejši prebivalci, je obrobje kmetijskih mest. Avtorji so med 27 analiziranimi razvojnimi strategijami našli deset, $v$ katerih je bil ta problem omenjen oziroma so bila najdena prostorsko segregirana območja na obrobju mesta (na primer v Baji). V obdobju komunizma so se uradne oblasti želele znebiti raztresenih kmetij, zato je do leta 1986 na teh območjih veljala prepoved gradnje. Raztresene kmetije so zato običajno v slabem stanju in neudobne za bivanje, saj so bile v glavnem zgrajene pred letom 1950. Prebivalci na teh območjih se starajo, imajo nizko izobrazbo, so brezposelni in pogosto živijo v revščini. Kljub slabim razmeram, v katerih živijo prvotni prebivalci, se na ta območja priseljujejo revni ljudje iz mest, ki imajo pogosto velike družine z veliko otroki. S selitvijo poskušajo ubežati mestni revščini, zato jih lahko obravnavamo kot socialne priseljence. Upajo, da bodo na teh območjih življenjski stroški nižji, vendar ne znajo upravljati majhnih kmetij, zato so njihova pričakovanja nerealna. Prvotni prebivalci območij raztresenih kmetij prišleke pogosto povezujejo s kriminalom. V primeru Szentesa so mediji poročali tudi o brezdomcih, ki so se naselili v prazne raztresene kmetije blizu mesta.

\section{6 Študija primera: Kecskemet}

\subsection{Prostorsko segregirana območja}

$\mathrm{Na}$ podlagi raziskave, opravljene na podlagi zgoraj opisanih metod, so avtorji določili naslednja segregirana območja $\mathrm{v}$ Kecskemetu: 1. urbani bloki v soseski Hetenyegyhaza, 2. urbani bloki ob ulici Teglagyar utca; 3. prostorsko segregirani urbani bloki v središču mesta, 4. urbani blok ob ulici Nagy Lajos kiraly körut, 5. urbani blok ob ulici Matyas kiraly körut, 6. urbani bloki v soseski Mükertvaros, 7. urbani bloki v soseski Muszaj, 8. urbani bloki ob ulici Löcsei utca, 9. urbani bloki v soseski Szeleifalu in 10. južni del mestnega središča. Območja so prikazana na sliki 4 a. Na sliki 4 b so prikazani predmestna 


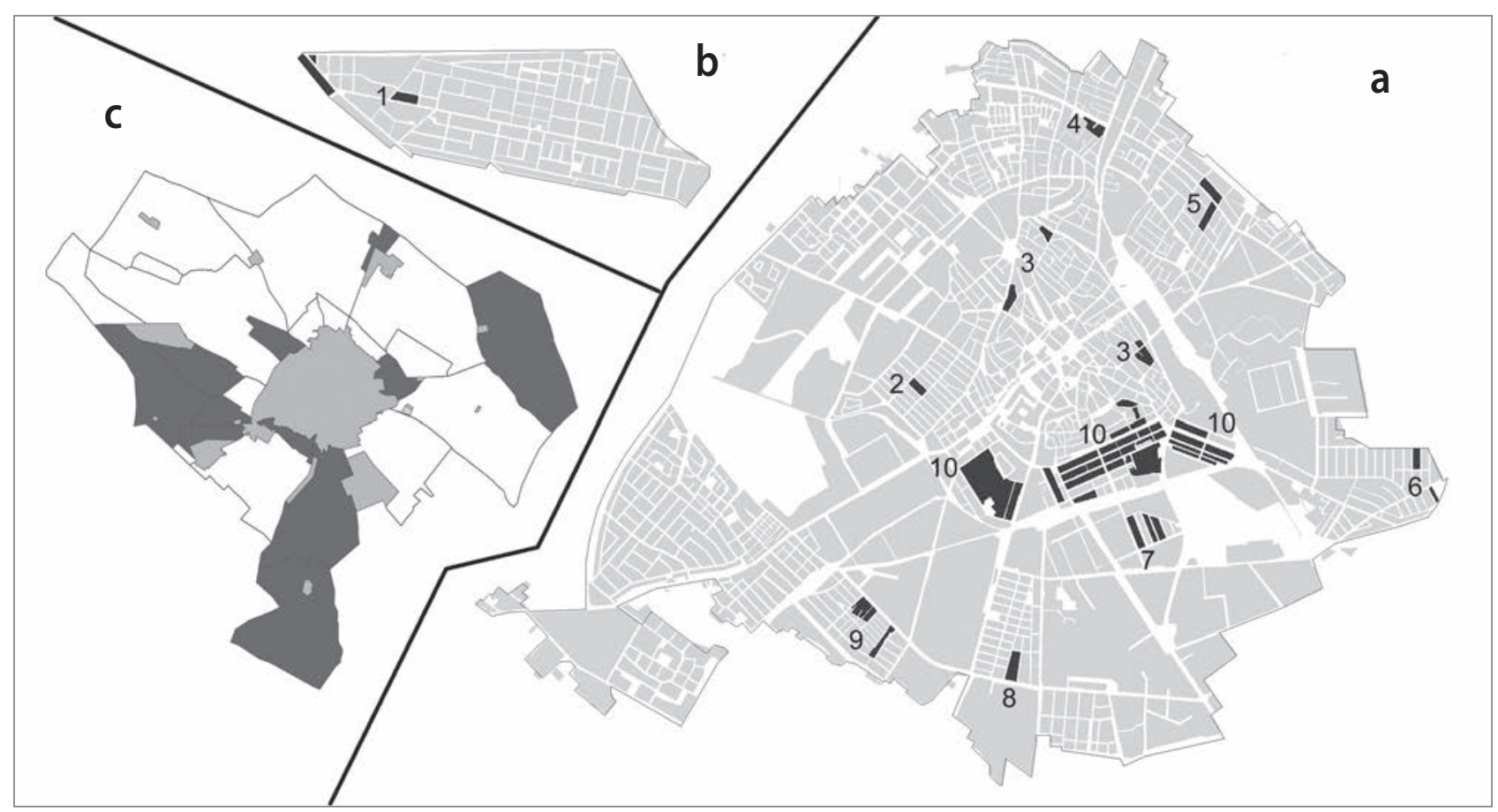

Slika 4: (a) segregirana območja v Kecskemetu; (b) soseska Hetenyegyhaza in tamkajšnji segregirani urbani bloki; (c) obrobje mesta z najbolj prostorsko segregiranimi raztresenimi kmetijami (avtorji: Jozsef Lennert, Jenö Zsolt Farkas in Andras Donat Kovacs, prirejeno na podlagi podatkov MCSU iz leta 2016 in popisa prebivalstva iz leta 2011)

soseska Hetenyegyhaza in njeni prostorsko segregirani urbani bloki, na sliki 4c pa so v temnejših odtenkih prikazani segregirani predeli mestnega obrobja.

\subsection{Stanje stanovanjskih objektov na prostorsko segregiranih območjih}

Grajeno okolje prostorsko segregiranih območij pogosto razkriva posledice negativnih družbenih procesov. Veliko je razpadajočih stavb, ki so celo življenjsko nevarne, a so bile še do pred kratkim naseljene. Na številnih praznih zemljiščih so divja odlagališča odpadkov, na stavbah in ulični opremi pa so vidni znaki vandalizma. Zaradi takšnih razmer so cene nepremičnin na teh območjih in v njihovi okolici nizke. Razmere so najbolj kritične v urbanih blokih, kjer med lokalnimi prebivalci prevladujejo Romi.

Nastanek in trajna prisotnost segregiranih območij sta v glavnem odvisna od starosti stavb in njihovega stanja (ki sta do neke mere soodvisna). V mestu je 49.665 stanovanj in hiš, od katerih je po podatkih MCSU 8.000 (16,3\%) starih več kot 50 let. Od teh je 3.057 (oziroma 6,1\% vseh stanovanj) v slabem stanju in ne izpolnjujejo minimalnih standardov udobja. Večina teh nepremičnin je na segregiranih območjih in če se hiše na njih ne bodo obnovile, bodo še naprej privabljale samo revne priseljence in še okrepile negativne procese. Stanje stavb $v$ lasti lokalne uprave je treba zaradi njihovih posebnih značil- nosti analizirati posebej. Leta 2012 je bilo v lasti lokalne uprave 1.596 stanovanjskih enot, od katerih se je 600 hiš, ki so bile večinoma v slabem stanju, uporabljalo za socialna stanovanja. Število socialnih stanovanj pada (leta 2016 jih je bilo 508), večina pa je na prostorsko segregiranih območjih. Glavna težava so najemnine, ki ne vključujejo stroškov vzdrževanja, zato mestna družba za upravljanje nepremičnin teh stavb ne more vzdrževati. Njihovo stanje se zato vztrajno slabša.

\subsection{Značilnosti prostorsko segregiranih območij $z$ etnično večino in poskusi reševanja problema}

Največje prostorsko segregirano območje z večinskim romskim prebivalstvom je že omenjena romska četrt (madž. Ciganyvaros) jugovzhodno od mestnega središča, kjer obstaja že stoletja (slika 5). V šestdesetih in sedemdesetih letih 20. stoletja se je zaradi načrtovanega rušenja nekaterih urbanih blokov na tem območju prostorska koncentracija romskih prebivalcev zmanjšala, po letu 1990, ko je lokalna uprava porušila začasna bivalǐ̌ča v mestnem središču (romska dvorišča), pa so se Romi preselili nazaj v okolico romske četrti. Tako se je staro prostorsko segregirano območje ponovno vzpostavilo, stavbe pa so začele propadati.

Zaradi čedalje slabših stanovanjskih razmer, v katerih so živeli romski prebivalci, je lokalna uprava leta 2002 začela izvajati program za njihovo izselitev iz barak, ki so bile v lasti mesta. 

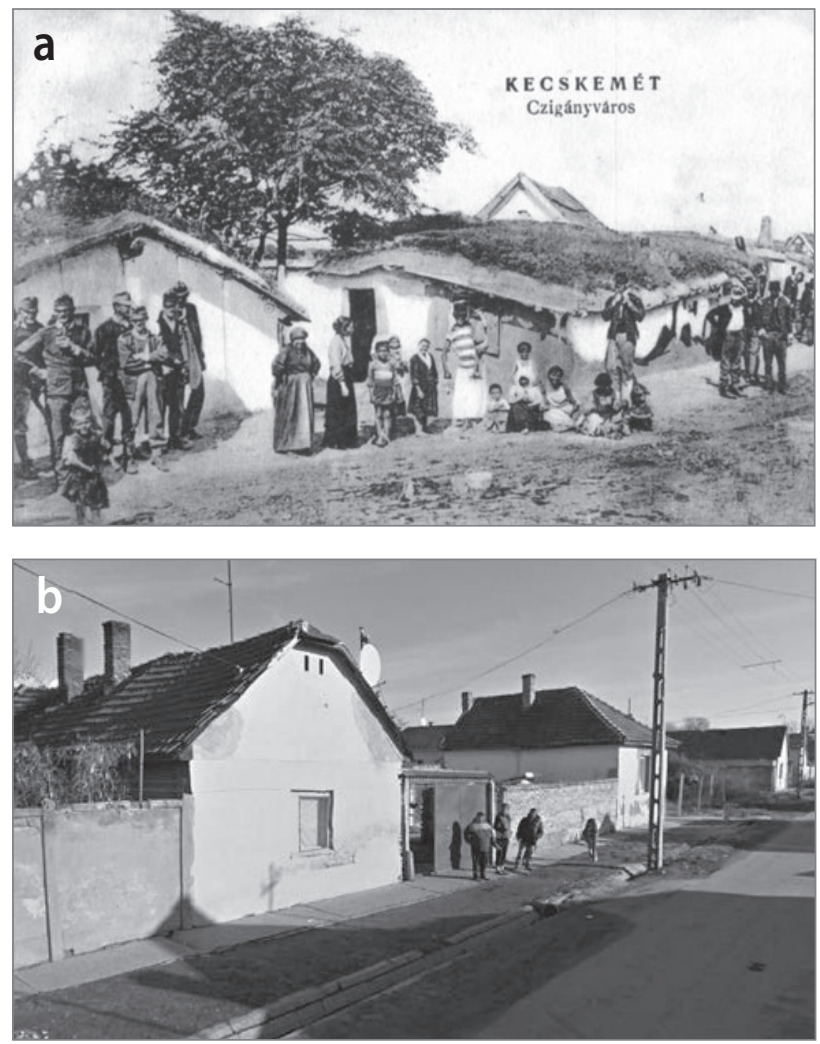

Slika 5: (a) romska četrt na razglednici iz leta 1930 (vir: internet 8); (b) današnje siromašne hiše v romski četrti (vir: Google Street View, 2012)

Dvesto romskih družin, ki so sodelovale v programu (30 \% vseh Romov v mestu), je lahko izbiralo med tema možnostma: zamenjava hiše ali zakup nepremičnine. Ker barake niso imele tržne vrednosti, je za njihov zakup lokalna uprava vsaki družini ponudila skromno vsoto 5.700 EUR. Sto družin, ki se je odločilo za to možnost, si je lahko privoščilo samo počitniške hišice ali kmetije na obrobju mesta. Anketiranci so opozorili na to, da so se z odpravo barak težave romske manjšine samo preselile na obrobje mesta, kar je imelo negativne posledice za soseske, kamor so se ti ljudje preselili, saj se je vrednost teh sosesk zmanjšala.

Mestne oblasti so program nadaljevale leta 2006 in takrat je v njem sodelovalo 50 družin, od katerih se je večina odločila za možnost zamenjave doma in je zapustila svoje hiše. Ti ukrepi so začasno omilili prostorsko segregacijo Romov, vendar so se prostorski vzorci segregacije kmalu spet pojavili. Zaposlitvene priložnosti so privabile nove romske družine iz drugih mest, ki so se večinoma preselile $\mathrm{v}$ ulice $\mathrm{v}$ okolici nekdanjega barakarskega naselja, saj so bile tam nepremičnine cenejše.

Za reševanje tega problema je mestni svet začel izvajati program celostne socialne urbane prenove, ki ga je prek operativnega programa statistične regije Južna velika nižina podprla tudi Evropska unija. Cilj projekta je bil spodbuditi družbeno vključevanje Romov, ki živijo v romski četrti in predelu
Ürges, pri čemer se je agencija za razvoj mesta osredotočila na izboljšanje bivalnih razmer, obnovo javne infrastrukture in okrepitev lokalne identitete. Konkretni rezultati projekta so vključevali dvanajst prenovljenih javnih najemnih stanovanj, novo večnamensko občinsko dvorano in novo urejena javna območja z novo ulično opremo in obnovljenimi cestami. Projekt je vseboval tudi socialne prvine, kot so razvoj skupnosti, kulturne storitve in nudenje socialne pomoči družinam. Projekt še vedno poteka in čeprav je nedvomno prinesel pozitivne rezultate, problema ni rešil.

\subsection{Segregacijski procesi na obrobju mesta}

Eden izmed izhodov v sili za revne prebivalce vodi na obrobje kmetijskih mest oziroma do tamkajšnjih raztresenih kmetij. Ta pojav je značilen tudi za Kecskemet, ki velja za največje kmetijsko mesto z največ raztresenimi kmetijami. Po podatkih popisa prebivalstva je leta 2011 na obrobju Kecskemeta živelo 17.281 ljudi ali $15 \%$ vseh njegovih prebivalcev (leta 2011 je v mestu živelo skupno 111.411 ljudi). Leta 2001 je na obrobju živelo samo 13.732 ljudi, kar pomeni, da se je njihovo število v zadnjem desetletju povečalo za $25 \%$. To je predvsem posledica dveh procesov: preseljevanja revnih ljudi s prostorsko segregiranih mestnih območij na raztresene kmetije in suburbanizacije premožnejšsih prebivalcev. Natančni deleži niso znani, avtorji pa ocenjujejo, da gre med obema skupinama za razmerje $50: 50$. Na podlagi intervjujev in terenskega dela so avtorji ugotovili, da ima obrobje Kecskemeta zelo razdrobljeno rabo tal. Na tem obrobju so vrtovi, stanovanjske soseske nizke gostote blizu pozidanega območja mesta (ali s povezavami do njega) in bolj oddaljene tradicionalne raztresene kmetije. Zaradi tega tam potekajo zelo različni procesi. Bližje mesta živijo premožnejši ljudje (včasih tudi v razkošnih hišah kot na primer v soseskah Mariahegy in Urihegy), ljudje s prostorsko segregiranih območij pa se selijo na bolj oddaljene raztresene kmetije. V zadnjih dveh desetletjih se je delež socialno ogroženih ljudi močno povečal tako $\mathrm{v}$ zahodnem kot vzhodnem delu mestnega obrobja (v predelih Szarkas, Borbas in Kisfai). Ljudje s slabšim socialno-ekonomskim položajem lahko tam kupujejo stavbe razmeroma poceni, saj je bilo v sistemu državnega socializma vse do leta 1986 prepovedano graditi raztresene kmetije in pripadajoče objekte, zaradi česar so stavbe tam zelo stare in poceni. Za tovrstno priseljevanje je ugodno tudi staranje tamkajšnjega prvotnega prebivalstva, saj so številne prazne stavbe še vedno primerne za bivanje, čeprav so običajno manj udobne.

Hkrati priseljenci nimajo potrebnih izkušenj za življenje na oddaljeni kmetiji, težko najdejo ustrezno zaposlitev, njihovi otroci pa čedalje težje redno obiskujejo šolo. Prvotni kmečki prebivalci jih stigmatizirajo, saj menijo, da je zaradi njih varnost na javnih mestih okrnjena, poleg tega jih povezujejo $s$ kriminalom. Razmere slabšajo tudi brezdomci, saj se tudi ti 
naseljujejo v prazne stavbe. Razmere so velik izziv socialnovarstvenim organizacijam, saj dostop do ljudi z nizkim socialnoekonomskim položajem postaja čedalje težji.

\section{Sklep}

Izsledki predstavljene raziskave kažejo, da je stanovanjska segregacija v kmetijskih mestih v madžarski statistični regiji Južna velika nižina pogost pojav. V nekaterih pogledih so tovrstni procesi podobni tistim $\mathrm{v}$ Zahodni Evropi in ZDA, vendar se od njih tudi razlikujejo. Vloga etnične pripadnosti pri segregaciji je najpogosteje ugotovljena skupna značilnost, na podlagi česar lahko na primer potegnemo vzporednico med položajem Romov na proučevanem območju in revnimi temnopoltimi prebivalci ameriških mest. Tudi poskusi reševanja te problematike so povsod enako neuspešni, saj se lokalne uprave običajno ukvarjajo samo z enim vidikom tega kompleksnega problema in se le malo ubadajo z vprašanji družbene vključenosti. Zaradi tega se stanovanjska segregacija skupaj s socialno in etnično segregacijo že več stoletij stalno pojavlja v drugih delih mesta, pogosto celo na istem območju.

Razlike v pojavnih oblikah segregacije med Zahodom in Madžarsko so večinoma posledica različne morfologije naselij. Naselja na proučevanem območju so manjša kot v Zahodni Evropi ali ZDA. Posledično je tudi njihovo staro mestno jedro manjše ter dragoceno za stanovalce in lokalno upravo, zato $\mathrm{v}$ središčih mest ni veliko primerov prostorske segregacije. Po drugi strani je v proučevanih mestih pogosta prostorska segregacija na obrobju neprekinjeno pozidanih območij. V nekaterih primerih je območje današnje prostorske segregacije geografsko povezano z nekdanjimi romskimi predeli, drugje pa se je razvila $\mathrm{v}$ povezavi $\mathrm{z}$ drugimi neugodnimi lokacijami. Stanovanjski fond $\mathrm{v}$ soseskah proučevanih mest je zelo raznolik in ima obliko krpanke, saj so pozidana območja pogosto prekinjena ali spremenijo smer. Zato segregacija nastaja bolj na ravni ulic kot okrožij, zaradi česar so značilni predvsem prostorsko segregirani urbani bloki, ne pa večja mestna območja.

Drug edinstven pojav, ki je tudi posledica različne morfologije naselij, je razvoj segregacije na mestnem obrobju. V soseske z vrtovi in na območja raztresenih kmetij, ki so tradicionalna prvina kmetijskih mest, se v zadnjem času selijo tako revnejši kot premožnejši prebivalci. Pri selitvi premožnejših skupin na podeželsko-mestno obrobje gre za suburbanizacijo v okviru občinskih meja, revnejše skupine pa poskušajo svoje življenjske stroške običajno znižati tako, da se odselijo s strnjeno pozidanih območij. Brez zadostnih izkušenj s samooskrbnim kmetovanjem pa so ti njihovi poskusi običajno neuspešni. Tako prišleki trpijo še večje pomanjkanje, poleg tega izgubijo tudi svojo socialno mrežo in so zunaj dosega organizacij, ki bi jim lahko zagotovile socialno pomoč.
Kecskemet je dober primer zgodovinskega in sodobnega razvoja stanovanjske segregacije. Z geografskega vidika so zdajšnja prostorsko segregirana območja blizu prejšnjega segregiranega območja romske četrti. Tudi pri sestavi tamkajšnjih prebivalcev ni večjih sprememb, saj gre večinoma za Rome. To je delno posledica napačno zastavljenega urbanističnega načrtovanja v 20. stoletju, pri katerem so bile etnične manjšine obravnavane kot zaprte skupine. Segregiranih območij niso nikoli povsem odstranili, poleg tega niso bila nikoli popolnoma prazna, saj so se nanje vedno naseljevali novi prišleki. Tudi njihova preselitev razmer ni izboljšala, saj so bili ljudje večinoma preseljeni na druga neugodna območja. Tako kot v drugih mestih v statistični regiji Južna velika nižina je preselitev revnejših prebivalcev na mestno obrobje tudi v Kecskemetu nekaj običajnega.

Analiza prostorsko segregiranih območij v Kecskemetu je pokazala močno povezavo med lokacijo prebivalcev z nizkim socialno-ekonomskim položajem in fizičnim stanjem stavb. Poleg tega so ta območja običajno tam, kjer je veliko socialnih stanovanj nizke kakovosti, ki so v lasti lokalne uprave. Zaradi tega imata mestni svet in agencija za razvoj mesta ključno vlogo pri upravljanju in prenovi tamkajšnjih prostorsko segregiranih urbanih blokov. Nezadostna finančna sredstva so glavni dejavnik, ki ovira razvoj teh območij. Čeprav so za mestno prenovo na razpolago nekatere subvencije EU, mestne oblasti brez ustreznih lokalnih sredstev ne morejo celostno izboljšati socialnih razmer v prostorsko segregiranih soseskah. Izsledki raziskave pa ne opozarjajo samo na pomanjkanje potrebnih sredstev, ampak tudi na pomembnost celovitega razmišljanja o stanovanjski segregaciji. Izboljšanje bivalnega okolja je samo prvi korak v procesu družbenega vključevanja, saj bi bilo treba socialno pomoč revnejšim prebivalcem zagotavljati tudi po izvedenih naložbah v infrastrukturo, s čimer bi preprečili ponovno pojavitev prostorske segregacije.

\section{Jenö Zsolt Farkas}

Institute for Regional Studies, Centre for Economic and Regional Studies, Hungarian Academy of Sciences, Kecskemet, Madžarska E-naslov: farkasj@rkk.hu

\section{Jozsef Lennert}

Institute for Regional Studies, Centre for Economic and Regional Studies, Hungarian Academy of Sciences, Kecskemet, Madžarska E-naslov: lennert@rkk.hu

\section{Andras Donat Kovacs}

Institute for Regional Studies, Centre for Economic and Regional Studies, Hungarian Academy of Sciences, Kecskemet, Madžarska E-naslov: kovacsa@rkk.hu

Imre Kanalas

Kecskemet Urban Development Ltd., Kecskemet, Madžarska E-naslov: kanalasimre@kecskemetivarosfejleszto.hu 


\section{Zahvala}

Raziskava, predstavljena $v$ tem članku, je bila finančno podprta $s$ štipendijo Janosa Bolyaia, ki jo podeljuje madžarska akademija znanosti.

\section{Viri in literatura}

Anthopolos, R., Kaufman, J. S., Messer, L. C., in Miranda, M. L. (2014): Racial residential segregation and preterm birth: Built environment as a mediator. Epidemiology, 25(3), str. 397-405.

DOI: $10.1097 /$ ede.0000000000000079

Bellman, B. (2014): Segregation and urban form: Towards an understanding of dynamics between race, population movement, and the built environment of American cities. Diplomsko delo. Dostopno na: http:// scholar.colorado.edu/honr theses/44 (sneto 14. 11. 2016).

Bjorvatn, K., in Cappelen, A. W. (2001): Inequality, segregation, and redistribution. Journal of Public Economics, 87(2003), str. 1657-1679. DOI: 10.1016/S0047-2727(01)00202-X

Bolt, G., Özüekren, A. S., in Phillips, D. (ur.) (2012): Linking integration and residential segregation. London, Routledge. DOI: $10.4324 / 9780203718490$

Burgess, E. W. (1928): Residential segregation in American cities. Annals of the American Academy of Political and Social Science, 140(1), str. 105115. DOI:10.1177/000271622814000115

Charles, C. Z. (2001): Processes of residential segregation. V: O'Connor A., Tilly, C., in Bobo, L. B. (ur.): Urban inequality: Evidence from four cities, str. 217-271. Russell Sage Foundation. DOI:10.1017/s0022050701005812

Charles, C. Z. (2003): The dynamics of residential segregation. Annual Review of Sociology, 29, str. 197-207.

DOI: 10.1146/annurev.soc.29.010202.100002

Clark, W. A. V., in Ware, J. (1997): Trends in residential integration by socioeconomic status in southern California. Urban Affairs Review, 32(6), str. 825-843. DOI: 10.1177/1078087497032006

Csalog, Z. (1984): A cigánykérdés Magyarországon 1980 előtt. Magyar Füzetek, 14-15, str. 93-137.

Domokos, V., in Herczeg, B. (2010): Terra incognita: magyarországi szegény és cigánytelepek felmérése - első eredmények. Szociológiai Szemle, (20)3, str. 82-99.

Duncan, O. D., in Duncan, B. (1955a): A methodological analysis of segregation indexes. American Sociological Review, 20(2), str. 210-217. DOI: $10.2307 / 2088328$

Duncan, O. D., in Duncan. B. (1955b): Residential distribution and occupational stratification. American Journal of Sociology, 60(5), str. 493503. DOI:10.1086/221609

Duncan, O. D., in Duncan. B. (1957): The Negro population of Chicago: A study of residential succession. Chicago, University of Chicago Press.

Farley, R., Elaine L., Fielding, E. L., in Krysan, M. (1997): The residentia preferences of blacks and whites: A four-metropolis analysis. Housing Policy Debate, 8(4), str. 763-800. DOI:10.1080/10511482.1997.9521278

Gentile, M. (2004): Divided post-Soviet small cities? Residential segre gation and urban form in Leninogorsk and Zyryanovsk, Kazakhstan. Geografiska Annaler: Series B, Human Geography, 86(2), str. 117-136. DOI: 10.1111/j.0435-3684.2004.00157

Glazer, N., in Moynihan, D. P. (1963): Beyond the melting pot: The Negroes, Puerto Ricans, Jews, Italians, and Irish of New York City. Cambridge, MA, MIT Press. DOI:10.1001/jama.1963.03710110079027
Google Street View (2017): Street View Kecskemet. Dostopno na: https://www.google.hu/maps/place/Kecskem (sneto 10. 9. 2017)

Gyenizse, P., Trocsanyi, A., Pirisi, G., Bognar, Z., in Czigany, S. (2016): A multi-factor model developed on residents' opinions for the classification of urban residential areas. Geografi - Sbornik České geografické společnosti, 121(1), str. 1-31.

Hamnett, C. (2005): Urban forms. V: Cloke, P., Crang, P., in Goodwin, M. (ur.): Introducing human geographies, str. 425-438. London, Hodder Education.

Hamnett, C. (2010): Urban inequality and polarization. V: Wu, F., in Webster, C. (ur.): Marginalization in urban China: Comparative perspectives, str. 17-28. Houndmills, VB, Palgrave Macmillan. DOI:10.1057/9780230299122 2

Havas, G. (1999): A kistelepülések és a romák. V: Glatz, F. (ur.): A cigány ok Magyarországon, str. 163-204. Budimpešta, MTA.

Howell, A., in Timberlake, J. M. (2014): Racial and ethnic trends in the suburbanization of poverty in U.S. metropolitan areas, 1980-2010. Journal of Urban Affairs, 36(1), str. 79-98. DOI: 10.1111/juaf.12030

Illyés, G. (1936): Puszták népe. Budimpešta, Nyugat.

Internet 1: http://www.terport.hu/telepulesrendezes-fejlesztes/fejlesztesi-dokumentumok (sneto 11. 1. 2017)

Internet 2: http://www.sze.hu/ lados/NGB_RT015/varosfejlesztesi_kezikonyv_071004_vegleges_fin.pdf (sneto 11. 11. 2016).

Internet 3: http://kecskemetivarosfejleszto.hu/letoltesek/KecskemetMJV_IVS.pdf (sneto 11. 1. 2017).

Internet 4: https://www.palyazat.gov.hu/download.php?objectld=38840 (sneto 12. 1. 2017)

Internet 5: http://www.kecskemet.hu/ivs/20121207_Kecskemet_felulvizsgalt_Integralt_Varosfejlesztesi_Strategiaja_2012.pdf (sneto 15. 1 2017).

Internet 6: http://kecskemetivarosfejleszto.hu/wp-content/uploads/2017/01/KMJV_ITS_2014090.pdf (sneto 1. 12. 2016).

Internet 7: http://www.esri.com/arcgis/about-arcgis (sneto 21. 3. 2014). Internet 8: http://ciganyokrol.blog.hu/page/10 (sneto 10. 9. 2017).

Juhasz, I. (1998): Kecskemét város építéstörténete, Kecskeméti Füzetek 8. Kecskemet, Tiberias Bt.

Kallai, E., in Törzsök, E. (ur.) (2006): Átszervezések kora. Cigánynak lenni Magyarországon. Budimpešta, EOKIK.

Kemeny, I. (ur.) (2000): A magyarországi romák. Változó Világ 31. Budimpešta, Press Publica.

Kemeny, I., in Janky, B. (2004): Települési és lakásviszonyok. Beszélő, (9)4, str. 96-102.

Kocsis, K., in Kovacs, Z. (1999): A cigány népesség társadalomföldrajza. V: Glatz, F. (ur.): A cigányok Magyarországon, Magyarország az ezredfordulón, str. 13-21. Budimpešta, MTA.

Kovacs, Z. (2012): Residential segregation in Budapest before and after transition. V: Maloutas T., in Fujita, K. (ur.): Residential segregation in comparative perspective: Making sense of contextual diversity, str. 197216. London, Routledge.

Ladanyi, J., in Szelenyi, I. (2004): A kirekesztettség változó formái. Budimpešta, Napvilág Kiadó.

Lieberson, S. (1963): Ethnic patterns in American cities: A comparative study using data from ten urban centers. New York, Free Press.

Lloyd, C. D., Shuttleworth, I. G., in Wong, D. W. (ur.) (2014): Social-spatial segregation: concepts, processes and outcomes. Bristol, The Policy Press. DOI: 10.1332/policypress/9781447301356.001.0001 
Logan, J. R., in Stults, B. J. (2011): The persistence of segregation in the metropolis: New findings from the 2010 Census. Projekt US2010. Dostopno na: http://www.s4.brown.edu/us2010/Data/Report/report2.pdf. (sneto 10. 9. 2017).

Logan, J. R., Stults, B. J., in Farley, R. (2004): Segregation of minorities in the metropolis: Two decades of change. Demography, 141(1), str. 1-22. DOI:10.1353/dem.2004.0007

Madžarski centralni statistični urad (2008-2016): Statistical yearbooks. Budimpešta.

Madžarski centralni statistični urad (2011): Population Census. Budimpešta.

Maloutas, T., in Fujita, K. (ur.) (2012): Residential segregation in comparative perspective Making sense of contextual diversity. London, Routledge. DOI: 10.4324/9781315605661

Marcuse, P. (1997): The enclave, the citadel, and the ghetto: What has changed in the post-Fordist U.S. city. Urban Affairs Review, 33(2), str. 228-264. DOI: 10.1177/107808749703300206

Marquez, F. (2011): Santiago: Modernisation, segregation and urban identities in the twenty-first century. Urbani izziv 22(2), str. 86-97. DOI: 10.5379/urbani-izziv-en-2011-22-02-002

Massey, D. S., in Denton, N. A. (1988): The dimensions of residential segregation. Social Forces, 67(2), str. 281-315. DOI: 10.2307/2579183

Massey D. S., in Denton, N. A. (1993): American apartheid: Segregation and the making of the underclass. Cambridge, MA, Harvard University Press.

Meszaros, R. (ur.) (1990): Az urbanizáció térbeli folyamatai Szegeden. Szeged, JATE.

Morgan, B. S., in Norbury, J. (1981): Some further observations on the index of residential differentiation. Demography, (18)2, str. 251-256. DOI:10.2307/2061097

Musterd, S. (2003): Segregation and integration: A contested relationship, Journal of Ethnic and Migration Studies, (29)4, str. 623-641. DOI: $10.1080 / 1369183032000123422$

Musterd, S., in Ostendorf, W. J. M. (1998): Urban segregation and the welfare state: Inequality and exclusion in western cities. London, Routledge. DOI: $10.4324 / 9780203448533$

Park, R. E., Burgess, E. W., McKenzie, R. D., in Wirth, L. (1925): The city: Suggestions for investigation of human behavior in the urban environment. Chicago, University of Chicago Press.

Romany, P. (1973): A tanyarendszer ma. Budapest, Kossuth.

Sabater, A., in Finney, N. (2014): Demographic understandings of changes in ethnic residential segregation across the life course. V: Lloyd, C. D., Shuttleworth, I. G., in Wong, D. W. (ur.): Social-spatial segregation: concepts, processes and outcomes, str. 269-300. Bristol, The Policy Press. DOI:10.1332/policypress/9781447301356.003.0012

Schelling, T. C. (1971): Dynamic models of segregation. Journal of Mathematical Sociology, 1, str. 143-186.

DOI: 10.1080/0022250x.1971.9989794

Schelling, T. C. (1978): Micromotives and macrobehavior. New York, W. W. Norton.

Spielman, S. E., in Harrison, P. (2013): The co-evolution of residential segregation and the built environment at the turn of the 20th century: A Schelling model. Transactions in GIS, 18(1), str. 25-45.

DOI:10.1111/tgis.12014

Szabo, Z. (1937): Cifra nyomorúság: a Cserhát, Mátra, Bükk földje és népe. Budimpešta, Cserépfalvi.
Taeuber, K. F., in Taeuber, A. (1965): Negroes in cities: Residential segregation and neighborhood change. New York, Aldine.

Timar, J. (1993): Az alföldi szuburbanizáció néhány sajátossága. Alföldi Tanulmányok, 15, str. 217-232.

Vaattovaara, M. (2002): Future developments of residential differentiation in the Helsinki metropolitan area: Are we following the European model? Yearbook of Population Research in Finland, 38, str. 107-123.

Vasarus, G. (2016): Külterületi szuburbanizáció és szegregáció: Példák vidéki agglomerációk konfliktusaira. Településföldrajzi tanulmányok, 6(1), str. 84-94.

Virag, T. (2010): Kirekesztve: falusi gettók az ország peremén. Budimpešta, Akadémiai Kiadó.

Watson, T. (2006): Metropolitan growth, inequality and residential segregation by income. V: Burtless, G. T., in Pack, J. R. (ur.): Brookings-Wharton Papers on Urban Affairs, 1, str. 1-52. DOI:10.1353/urb.2006.0029

White, M. J. (1983): The measurement of spatial segregation. American Journal of Sociology, 88(5), str. 1008-1018. DOI: 10.1086/227768

Zhang, J. (2006): A dynamic model of residential segregation. Journal of Mathematical Sociology, 28, str. 147-170. DOI:10.1080/00222500490480202 